\title{
CORRELATION BETWEEN OCCURRENCE AND DETERIORATION OF RESPIRATORY DISEASES AND AIR POLLUTION WITHIN THE LEGALLY PERMISSIBLE LIMITS
}

\author{
Kristina Trnjar ${ }^{1}$, Sanja Pintarić ${ }^{2}$, Marko Mornar Jelavić ${ }^{3}$, Višnja Nesek ${ }^{4}$, Jelena Ostojić \\ Sanja Pleština ${ }^{6}$, Aljoša Šikić ${ }^{1}$ and Hrvoje Pintarić ${ }^{7}$
}

\begin{abstract}
${ }^{1}$ Sestre milosrdnice University Hospital Center; ${ }^{2}$ First School of Economics;
${ }^{3}$ Department of Internal Medicine and Dialysis, Zagreb-East Health Center;

${ }^{4}$ Sveti Duh University Hospital, Zagreb, School of Medicine, Zagreb, University of Osijek, Osijek;

${ }^{5}$ Special Hospital for Pulmonary Diseases; ${ }^{6}$ Zagreb University Hospital Center,

Clinical Department of Lung Diseases, Zagreb, School of Medicine, University of Rijeka, Rijeka;
\end{abstract}

${ }^{7}$ Sestre milosrdnice University Hospital Center, School of Dental Medicine, University of Zagreb, Zagreb, Croatia

\begin{abstract}
SUMMARY - The aim of the study was to investigate the unknown effect of air pollutants on the occurrence or deterioration of respiratory diseases in the area with a humid continental climate. This retrospective study included 5868 patients with respiratory symptomatology (upper respiratory tract infection (URTI), pneumonia, acute bronchitis, chronic obstructive pulmonary disease (COPD), and asthma) admitted to emergency department (ED). The number of patients, values of meteorological parameters (mean daily values of air temperature, pressure and relative humidity) and concentrations of air pollution particles $\left(\leq 10 \mu \mathrm{m}\left(\mathrm{PM}_{10}\right)\right.$, ozone $\left(\mathrm{O}_{3}\right)$ and nitrogen dioxide $\left.\left(\mathrm{NO}_{2}\right)\right)$ were collected during a two-year (July 2008 - June 2010) period. There were 1839 (31.3\%), 1712 (29.2\%), 1313 (22.4\%), $614(10.5 \%)$ and 390 (6.6\%) patients with pneumonia, COPD, URTI, acute bronchitis and asthma, respectively. The mean daily concentrations of $\mathrm{NO}_{2}\left(25.9(1.7-89.7) \mu \mathrm{g} / \mathrm{m}^{3}\right) \mathrm{O}_{3}(47.1(4.7-135.4) \mu \mathrm{g} /$ $\left.\mathrm{m}^{3}\right)$ and $\mathrm{PM}_{10}$ particles $\left(25.7(4.6-146.6) \mu \mathrm{g} / \mathrm{m}^{3}\right)$ were below the legally defined thresholds. Among other results, the occurrence of respiratory diseases showed positive Spearman's correlation with the values of air humidity (days 0-3, $r=0.15$ to 0.19 ), $\mathrm{PM}_{10}$ (days $0-3, r=0.10$ to 0.13 ) and $\mathrm{NO}_{2}$ concentrations (day $0, r=0.11$ ), and negative correlation with the values of air temperature (days $0-3, r=-0.36$ to -0.34 ), pressure (day $0, r=-0.10$ ) and $\mathrm{O}_{3}$ concentrations (days $0-3, r=-0.21$ to -0.22$)(\mathrm{p}<0.05$ all). In conclusion, the occurrence of respiratory diseases showed correlation with weather conditions and air pollutants despite the legally permitted values in the region with a humid continental climate.
\end{abstract}

Key words: Air pollution - adverse effects; Respiration disorders; Ozone; Nitrogen dioxide; Croatia

\section{Introduction}

Climate changes, which according to recent data have a worsening trend, pose great threat to respiratory

Correspondence to: Marko Mornar Jelavic, MD, PhD, Department of Internal Medicine and Dialysis, Zagreb-East Health Center, Ninska 10, HR-10000 Zagreb, Croatia

E-mail: mjelavic@yahoo.com

Received November 24, 2016, accepted January 3, 2017 health by directly promoting or aggravating respiratory diseases or through the increasing exposure to risk factors for respiratory diseases ${ }^{1}$. Climate change increase the amount of pollen and allergen produced by each plant, mould proliferation, and the concentrations of outdoor ozone $\left(\mathrm{O}_{3}\right)$ and particulate matter $(\mathrm{PM})$ at the ground level. The main diseases of concern are asthma, rhinosinusitis, chronic obstructive pulmonary disease (COPD) and respiratory tract infections 
(RTI). Groups at a higher risk of climate change effects include individuals with pre-existing cardiopulmonary diseases or disadvantaged individuals. Adaptation and mitigation measures are strongly needed ${ }^{1}$.

The exposure to air pollutants and changes of meteorological parameters (air temperature, humidity and pressure) may be related to higher morbidity and mortality, as well as to a higher number of patients presenting to emergency department $(\mathrm{ED})^{2-4}$. Air pollution poses great health risk even in developed countries with legally defined thresholds of air pollutant concentration $^{5,6}$.

Zagreb is the capital and the largest city $(790,017$ citizens, area $641 \mathrm{~km}^{2}$ ) of the Republic of Croatia, a country situated in southeastern Europe ${ }^{7}$. The climate of Zagreb is classified as a humid continental. The average daily temperature in winter is around $+1{ }^{\circ} \mathrm{C}$ (from December to February) and the average temperature in summer is $22.0^{\circ} \mathrm{C}$.

In this study, we investigated whether $\mathrm{PM}$ particles sized $\leq 10$ micrometers $\left(\mathrm{PM}_{10}\right)$, nitrogen dioxide $\left(\mathrm{NO}_{2}\right)$ and $\mathrm{O}_{3}$, as well as certain meteorological conditions had impact on ED visits of patients with various respiratory diseases in our area with a humid continental climate.

\section{Subjects and Methods}

This retrospective study included 5868 consecutive patients admitted to ED (Sestre milosrdnice University Hospital Center and Sveti Duh University Hospital) during a two-year period (June 2008 - July 2010). All patients were Zagreb residents. Information on daily ED visits were collected retrospectively from the information systems of the two hospitals. The study was approved by the institutional Ethics Committee. Given the observational design of the study, informed consent was waived. According to clinical presentation, radiology and laboratory findings, patients were classified into five groups, as follows: pneumonia, acute bronchitis, COPD, asthma, and upper respiratory tract infection (URTI). The concentrations of $\mathrm{NO}_{2}, \mathrm{O}_{3}$ and $\mathrm{PM}_{10}$ particles were collected by the National Monitoring Station Zagreb -1 (Environmental Protection Agency). The mean daily values of air temperature $\left({ }^{\circ} \mathrm{C}\right)$, pressure $(\mathrm{kPa})$ and relative humidity $(\%)$ were collected by the Meteorological and Hydrological Service of Croatia.

\section{Statistical analysis}

Qualitative data were expressed as absolute number and percentage. We used $\chi^{2}$-test with Yates correction for analysis. Quantitative data were expressed as median and range. Differences between two and among three or more groups were tested by MannWhitney U-test and Kruskal-Wallis ANOVA test, respectively. Correlation between the number of patients with respiratory symptomatology, values of meteorological parameters and concentrations of air pollutants was assessed by nonparametric Spearman's correlation test. It was classified by Spearman's $r$ value as very weak (0-0.19), weak (0.20-0.39), moderate (0.40$0.59)$, strong $(0.60-0.79)$, and very strong $(0.80-1.0)$ correlation. This guide also applied to negative correlations. The level of statistical significance was set at $\mathrm{p}<0.05$. Processing was done using the STATISTICA 6.0 for Windows software.

\section{Results}

Of the total of 5868 patients, there were 1839 (31.3\%), 1712 (29.2\%), 1313 (22.4\%), 614 (10.5\%) and $390(6.6 \%)$ patients with pneumonia, COPD, URTI, acute bronchitis and asthma, respectively (Fig. 1). We recorded the following results:

1. The occurrence of acute bronchitis, asthma and URTI was higher in females, and of pneumonia and COPD in males (Fig. 1). Age differences between males and females according to type of respiratory disease are presented in Table 1 . Females with pneumonia, acute bronchitis, COPD and asthma were significantly older $(p<0.05)$.

2. During the study period, the mean daily values of $\mathrm{NO}_{2}\left(25.9(1.7-89.7) \mu \mathrm{g} / \mathrm{m}^{3}\right) \mathrm{O}_{3}(47.1$ (4.7135.4) $\mu \mathrm{g} / \mathrm{m}^{3}$ ) and $\mathrm{PM}_{10}(25.7(4.6-146.6) \mu \mathrm{g} /$ $\left.\mathrm{m}^{3}\right)$ were below the legally defined thresholds. Regarding the humid continental climate characteristics, the given mean daily values of air temperature $\left(13.4(-7.9-28.5){ }^{\circ} \mathrm{C}\right)$, relative humidity (68.9 (37.7-95.3) \%) and air pressure (996 (966-1020) hPa) were expected.

3. Spearman's correlation analysis yielded the following significant results (Tables 2 and 3):

a. total number of patients with respiratory symptomatology correlated with higher values of air humidity (days 0-3), $\mathrm{PM}_{10}$ (days $0-3$ ) and $\mathrm{NO}_{2}$ (day 0) concentrations, and 


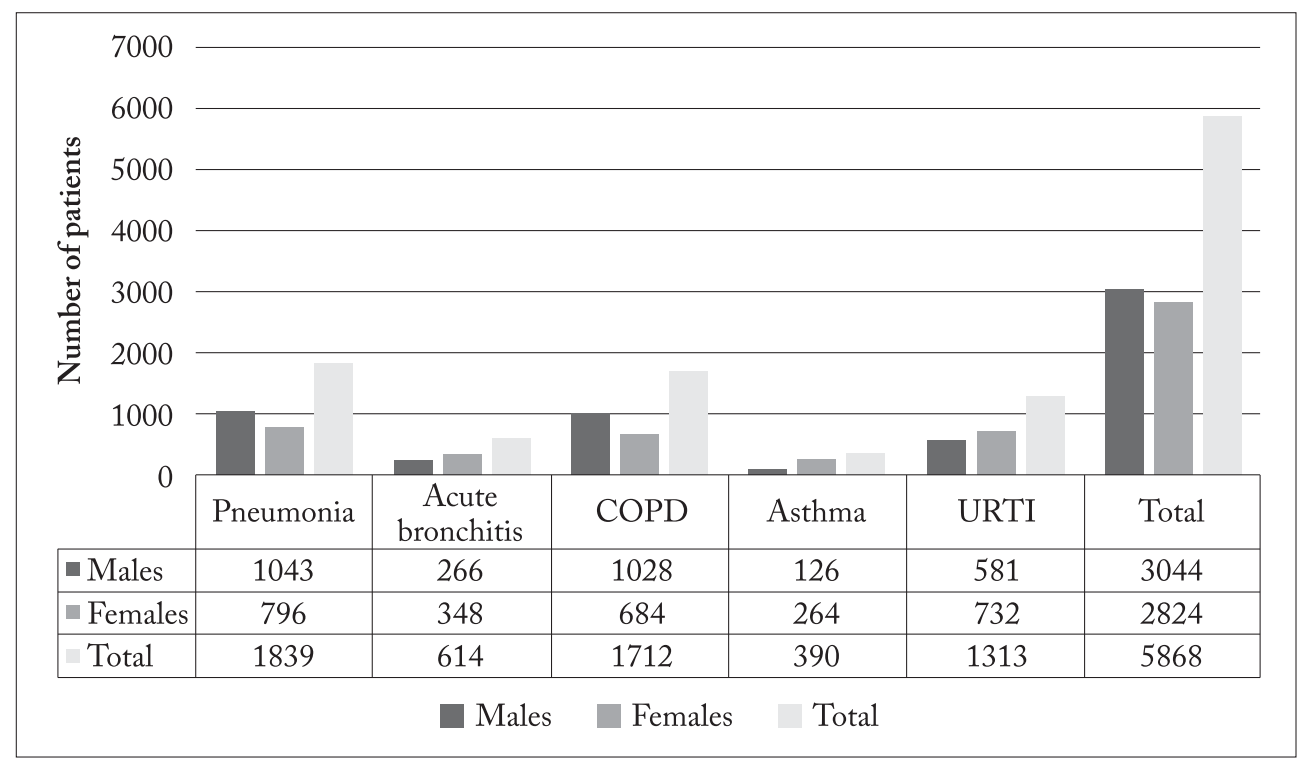

COPD = chronic obstructive pulmonary disease; URTI = upper respiratory tract infection

Fig. 1. Number of patients with respiratory diseases (pneumonia, acute bronchitis, COPD, asthma and URTI) admitted to emergency department during a two-year period (July 2008 - June 2010).

with lower values of air temperature (days $0-3)$, pressure (day 0 ) and $\mathrm{O}_{3}$ concentration (days $0-3$;

b. the occurrence of pneumonia correlated with higher values of air humidity, $\mathrm{PM}_{10}$ and $\mathrm{NO}_{2}$ concentrations (days 0 and 1 ), and with lower values of air temperature (days 0-3) and $\mathrm{O}_{3}$ concentration (days 0 and 1 );

c. the number of patients with acute bronchitis correlated with higher values of air humidity (days 0-3) and $\mathrm{PM}_{10}$ concentration (days 2 and 3 ), and with lower values of air temperature and $\mathrm{O}_{3}$ concentration (days 0-3);

d. the occurrence of COPD correlated with higher values of air humidity (days 0-3) and $\mathrm{PM}_{10}$ concentration (day 1), and with lower values of air temperature (days 0-3), air pressure (days 0 and 1 ) and $\mathrm{O}_{3}$ concentration (days 0-3);

e. the occurrence of asthma correlated with higher and lower values of $\mathrm{O}_{3}$ (days 0 and 3) and $\mathrm{PM}_{10}$ (days 0 and 2) concentrations, respectively; and

f. the occurrence of URTI correlated with higher values of air humidity (days $0-3$ ) and
$\mathrm{PM}_{10}$ concentration (days 0-2), and with lower values of air temperature (days 0-3), air pressure (day 0 ) and $\mathrm{O}_{3}$ concentration (days 0-3).

\section{Discussion}

As already mentioned, this study investigated the impact of air pollutants and weather conditions on the occurrence of respiratory diseases in the area with a humid continental climate. It is important to emphasize that during the study period, daily concentrations of air pollutants were below the legally permissible upper limits.

In our study, the number of patients with respiratory diseases (except for asthma) correlated with higher and lower values of air humidity and temperature, respectively. Also, the number of patients with COPD correlated with lower air pressure. Cold temperature and low humidity were associated with increased occurrence of $\mathrm{RTI}^{8}$. Both of these conditions favor the spread of some viruses such as influenza virus ${ }^{9-11}$, which through positive correlation with changes in the host physiological susceptibility, immune function, and behavioral patterns (cross-infection from indoor crowd- 
Table 1. Age differences between males and females according to type of respiratory disease

\begin{tabular}{|l|l|l|l|}
\hline Diagnosis & $\begin{array}{l}\text { Male } \\
\text { (median } \\
\text { and range) }\end{array}$ & $\begin{array}{l}\text { Female } \\
\text { (median } \\
\text { and range) }\end{array}$ & $\begin{array}{l}\text { Mann- } \\
\text {-Whitney } \\
\text { U test }\end{array}$ \\
\hline Pneumonia & $69(17-97)$ & $74(16-99)$ & $\mathrm{p}<0.001$ \\
\hline $\begin{array}{l}\text { Acute } \\
\text { bronchitis }\end{array}$ & $52(15-91)$ & $60(18-96)$ & $\mathrm{p}<0.001$ \\
\hline COPD & $74(20-93)$ & $76(17-100)$ & $\mathrm{P}<0.001$ \\
\hline Asthma & $36(15-88)$ & $49(15-86)$ & $\mathrm{p}=0.005$ \\
\hline URTI & $43(14-92)$ & $42(13-98)$ & $\mathrm{p}=0.265$ \\
\hline $\begin{array}{l}\text { Kruskal-Wallis } \\
\text { ANOVA }\end{array}$ & $\mathrm{p}<0.001$ & $\mathrm{p}<0.001$ & \\
\hline
\end{tabular}

$\mathrm{COPD}=$ chronic obstructive pulmonary disease; URTI $=$ upper respiratory tract infection ing) results in a higher rate of RTI. Other authors report on positive and negative RTI correlation with air humidity and temperature ${ }^{12}$. The higher incidence of COPD and asthma exacerbations during the periods of cold temperature has important consequences for patients in terms of increased morbidity and mortality ${ }^{13-15}$. It could be due to the increased prevalence of viral RTI circulating in cold conditions. In addition, other meteorological conditions such as high atmospheric pressure and low humidity can directly induce asthma and $\mathrm{COPD}^{15-17}$.

Primary pollutants (e.g., nitrogen dioxide, $\mathrm{NO}_{2}$ ) are released directly into the atmosphere, whereas secondary pollutants (e.g., ozone, $\mathrm{O}_{3}$ ) result from chemical reactions among them. The most extensively studied pollutant is PM, which can be primary or second-

Table 2. Correlations between meteorological parameters and occurrence of respiratory diseases (July 2008-June 2010)

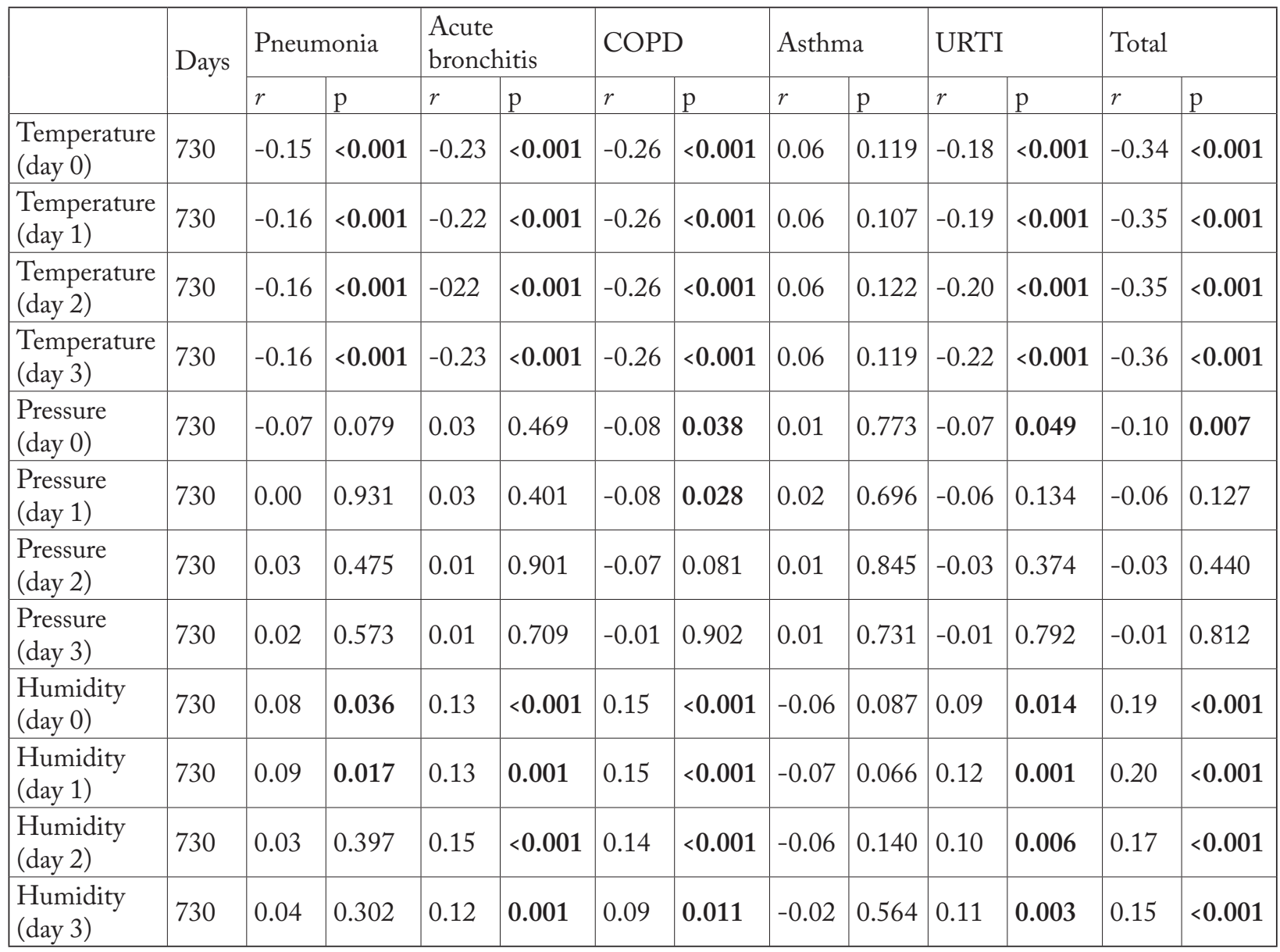

COPD = chronic obstructive pulmonary disease; URTI = upper respiratory tract infection; $r$ = Spearman's rank order correlation coefficient; day 0 = day of emergency department (ED) visit; days 1-3 = days before ED visit 
ary, and varies in number, size, shape, surface area, and chemical composition ${ }^{18}$. In contact with respiratory epithelium, high concentrations of oxidants and prooxidants in environmental pollutants cause the formation of free radicals and initiate inflammatory response through involvement of inflammatory cells and mediators. They reach systemic circulation, leading to subclinical inflammation and negative respiratory and systemic effects. Acute effects are manifested shortly after exposure (hours or days), whereas chronic effects are usually assessed in longitudinal studies over years or decades ${ }^{18}$.

Particulate matter particles cause respiratory morbidity and mortality by inducing oxidative stress and inflammation that lead to pulmonary anatomic and physiologic remodeling ${ }^{19}$. Association with $\mathrm{PM}_{10}$ has been reported for asthma ${ }^{20-25}$, URTI and pneumonia ${ }^{22}$, COPD exacerbations ${ }^{24-28}$, as well as for all respiratory visits $^{20,29,30}$. In our study, the number of patients with respiratory diseases (except for asthma) correlated with higher $\mathrm{PM}_{10}$ concentrations, confirming its role as the most powerful air pollutant generated by burning of fossil fuels in vehicles and other causes.

Nitrogen dioxide is a primary pollutant and strong respiratory irritant, with the main outdoor sources including motor vehicles and fossil-fuel power plants, whereas the most important indoor sources are gas heaters, stoves and tobacco smoke ${ }^{31,32}$. $\mathrm{NO}_{2}$ is associated with asthma visits ${ }^{21,23-25,29,33}, \mathrm{COPD}^{22,33,34}, \mathrm{URTI}^{22}$, pneumonia ${ }^{29}$, as well as all respiratory ED visits ${ }^{35,36}$. Samoli et al. found significant association of $\mathrm{NO}_{2}$ with total, cardiovascular and respiratory mortality ${ }^{31}$. Shahi

Table 3. Correlations between air pollutants and occurrence of respiratory diseases (July 2008 - June 2010)

\begin{tabular}{|c|c|c|c|c|c|c|c|c|c|c|c|c|c|}
\hline & \multirow{2}{*}{ Days } & \multicolumn{2}{|c|}{ Pneumonia } & \multicolumn{2}{|c|}{ Acute bronchitis } & \multicolumn{2}{|c|}{ COPD } & \multicolumn{2}{|c|}{ Asthma } & \multicolumn{2}{|c|}{ URTI } & \multicolumn{2}{|l|}{ Total } \\
\hline & & $r$ & $\mathrm{p}$ & $r$ & $\mathrm{p}$ & $r$ & $\mathrm{p}$ & $r$ & $\mathrm{p}$ & $r$ & $\mathrm{p}$ & $r$ & $\mathrm{p}$ \\
\hline $\begin{array}{l}\mathrm{PM}_{10} \\
(\text { day 0) }\end{array}$ & 720 & 0.09 & 0.015 & 0.12 & 0.001 & 0.07 & 0.063 & -0.08 & 0.026 & 0.08 & 0.036 & 0.13 & $<0.001$ \\
\hline $\begin{array}{l}\mathrm{PM}_{10} \\
\text { (day 1) }\end{array}$ & 719 & 0.09 & 0.012 & 0.07 & 0.057 & 0.08 & 0.039 & -0.05 & 0.163 & 0.09 & 0.023 & 0.13 & 0.001 \\
\hline $\begin{array}{l}\mathrm{PM}_{10} \\
\text { (day 2) }\end{array}$ & 718 & 0.07 & 0.051 & 0.09 & 0.017 & 0.03 & 0.380 & -0.07 & 0.049 & 0.08 & 0.039 & 0.10 & 0.005 \\
\hline $\begin{array}{l}\mathrm{PM}_{10} \\
\text { (day 3) }\end{array}$ & 717 & 0.06 & 0.091 & 0.13 & 0.001 & 0.04 & 0.324 & -0.06 & 0.117 & 0.07 & 0.075 & 0.10 & 0.007 \\
\hline $\begin{array}{l}\mathrm{NO}_{2} \\
(\text { day } 0)\end{array}$ & 692 & 0.10 & 0.009 & 0.07 & 0.071 & 0.06 & 0.142 & 0.00 & 0.963 & 0.02 & 0.610 & 0.11 & 0.004 \\
\hline $\begin{array}{l}\mathrm{NO}_{2} \\
(\text { day } 1)\end{array}$ & 692 & 0.09 & 0.016 & 0.03 & 0.503 & 0.00 & 0.933 & -0.02 & 0.621 & 0.07 & 0.082 & 0.07 & 0.065 \\
\hline $\begin{array}{l}\mathrm{NO}_{2} \\
\text { (day 2) }\end{array}$ & 692 & 0.03 & 0.414 & 0.05 & 0.176 & -0.01 & 0.759 & -0.01 & 0.899 & 0.03 & 0.477 & 0.04 & 0.287 \\
\hline $\begin{array}{l}\mathrm{NO}_{2} \\
\text { (day } 3 \text { ) }\end{array}$ & 692 & 0.05 & 0.174 & 0.06 & 0.115 & 0.00 & 0.912 & -0.03 & 0.398 & 0.06 & 0.125 & 0.06 & 0.110 \\
\hline $\begin{array}{l}\mathrm{O}_{3} \\
(\text { day } 0)\end{array}$ & 646 & -0.09 & 0.017 & -0.18 & $<0.001$ & -0.16 & $<0.001$ & 0.08 & 0.037 & -0.11 & 0.005 & -0.21 & $<0.001$ \\
\hline $\begin{array}{l}\mathrm{O}_{3} \\
(\text { day 1) }\end{array}$ & 646 & -0.09 & 0.021 & -0.15 & $<0.001$ & -0.15 & $<0.001$ & 0.05 & 0.191 & -0.13 & 0.001 & -0.22 & $<0.001$ \\
\hline $\begin{array}{l}\mathrm{O}_{3} \\
\text { (day 2) }\end{array}$ & 646 & -0.07 & 0.088 & -0.15 & $<0.001$ & -0.14 & $<0.001$ & 0.06 & 0.104 & -0.15 & $<0.001$ & -0.21 & $<0.001$ \\
\hline $\begin{array}{l}\mathrm{O}_{3} \\
\text { (day 3) }\end{array}$ & 646 & -0.07 & 0.090 & -0.15 & $<0.001$ & -0.14 & $<0.001$ & 0.06 & 0.026 & -0.18 & $<0.001$ & -0.22 & $<0.001$ \\
\hline
\end{tabular}

COPD = chronic obstructive pulmonary disease; URTI = upper respiratory tract infection; day 0 = day of emergency department $(\mathrm{ED})$ visit; days 1-3 = days before ED visit; $r$ = Spearman's rank order correlation coefficient 
et al. found that altered levels of $\mathrm{NO}_{2}$ had no effects on respiratory admissions ${ }^{37}$. We found the number of patients with pneumonia to correlate with higher $\mathrm{NO}_{2}$ concentrations.

Ozone is a powerful oxidant that can damage respiratory tract, causing inflammation and irritation. Several studies report on $\mathrm{O}_{3}$ to be associated with asthma ${ }^{22,23,25,34,38}$, acute and chronic bronchitis ${ }^{39}$, $\mathrm{URTI}^{22}$, and all respiratory visits ${ }^{27,29,30,38}$. Tamayo-Uria et al. report that $\mathrm{O}_{3}$ is negatively associated with $\mathrm{COPD}^{28}$. We found the number of patients with asthma to correlate with $\mathrm{O}_{3}$ concentrations.

Vaduganathan et al. investigated the association between exposure to air pollutants $\left(\mathrm{PM}_{10}\right.$ particles) and acute cardiovascular $(\mathrm{CV})$ events ${ }^{4}$. They concluded that increased levels of $\mathrm{PM}_{10}$, even below the current limits set by the European Union, were associated with excess risk of admissions for acute $\mathrm{CV}$ events.

The results of our study should be considered in the light of certain limitations. The study period was rather short. The $\mathrm{O}_{3}$ data were taken from only one monitoring station, which may have led to misclassification of exposure level. Moreover, there is a lack of precise exposure estimates at individual level due to different daily activity patterns and local mobility of each patient. There are many factors that may influence the prevalence of pulmonary disease admissions, which were not taken into account.

In conclusion, weather conditions and air pollutants have a role in the higher occurrence of respiratory diseases in the area with a humid continental climate. We would like to emphasize two important facts, i.e. the need for better cooperation of hydrometeorology services and media on informing the population about weather conditions, and the need to decrease the legally permissible upper limits of air pollution. It is very important because air pollution within the currently permissible levels increases the number of pulmonary patients examined in ED.

\section{References}

1. D’Amato G, Cecchi L, D'Amato M, Annesi-Maesano I. Climate change and respiratory diseases. Eur Respir Rev. 2014; 23:161-9. https://doi.org/10.1183/09059180.00001714

2. Qian Z, Lin HM, Stewart WF, Kong L, Xu F, Zhou D, et al. Seasonal pattern of the acute mortality effects of air pollution. J Air Waste Manag Assoc. 2010;60:481-8.
3. Colais P, Serinelli M, Faustini A, Stafoggia M, Randi G, Tessari $\mathrm{R}$, et al. Air pollution and urgent hospital admissions in nine Italian cities. Results of the EpiAir Project. Epidemiol Prev. 2009;33:77-94.

4. Vaduganathan M, De Palma G, Manerba A, Goldoni M, Triggiani M, Apostoli P, et al. Risk of cardiovascular hospitalizations from exposure to coarse particulate matter (PM10) below the European Union safety threshold. Am J Cardiol. 2016;117:12315. https://doi.org/10.1016/j.amjcard.2016.01.041

5. Kraft M, Eikmann T, Kappos A, Künzli N, Rapp R, Schneider $\mathrm{K}$, et al. The German view: effects of nitrogen dioxide on human health - derivation of health-related short-term and longterm values. Int J Hyg Environ Health. 2005;208:305-18. https://doi.org/10.1016/j.ijheh.2005.04.002

6. Samoli E, Aga E, Touloumi G, Nisiotis K, Forsberg B, Lefranc $A$, et al. Short-term effects of nitrogen dioxide on mortality: an analysis within the APHEA project. Eur Respir J. 2006; 27:1129-38. https://doi.org/10.1183/09031936.06.00143905

7. City of Zagreb. Zagreb in brief. The official City of Zagreb website, http://www.zagreb.hr/default.aspx?id=1125; 2014 [accessed 2014].

8. Mäkinen TM, Juvonen R, Jokelainen J, Harju TH, Peitso A, Bloigu A, et al. Cold temperature and low humidity are associated with increased occurrence of respiratory tract infections. Respir Med. 2009;103:456-62. https://doi.org/10.1016/j. rmed.2008.09.011

9. Dowell SF, Ho MS. Seasonality of infectious diseases and severe acute respiratory syndrome - what we don't know can hurt us. Lancet Infect Dis. 2004;4:704-8. https://doi.org/10.1016/ S1473-3099(04)01177-6

10. Lowen AC, Mubareka S, Steel J, Palese P. Influenza virus transmission is dependent on relative humidity and temperature. PLoS Pathog. 2007;3:1470-6. https://doi.org/10.1371/journal. ppat.0030151

11. Hemmes JH, Winkler KC, Kool SM. Virus survival as a seasonal factor in influenza and poliomyelitis. Antonie Van Leeuwenhoek. 1962;28:221-33.

12. Falagas ME, Theocharis G, Spanos A, Vlara LA, Issaris EA, Panos $G$, et al. Effect of meteorological variables on the incidence of respiratory tract infections. Respir Med.2008;102:7337. https://doi.org/10.1016/j.rmed.2007.12.010

13. Donaldson GC, Wedzicha JA. The causes and consequences of seasonal variation in COPD exacerbations. Int J Chron Obstruct Pulmon Dis. 2014;9:1101-10. https://doi.org/10.2147/ COPD.S54475

14. Hansel NN, McCormack MC, Kim V. The effects of air pollution and temperature on COPD. COPD. 2016;13:372-9. https://doi.org/10.3109/15412555.2015.1089846

15. Wang W. Progress in the impact of polluted meteorological conditions on the incidence of asthma. J Thorac Dis. 2016;8: E57-61. https://doi.org/10.3978/j.issn.2072-1439.2015.12.64

16. Tseng C, Chen Y, Ou S, Hsiao Y, Li S, Wang SJ, et al. The effect of cold temperature on increased exacerbation of chronic ob- 
structive pulmonary disease: a nationwide study. PLoS ONE. 2013;8:e57066. https://doi.org/10.1371/journal.pone.0057066

17. Ferrari U, Exner T, Wanka ER, Bergemann C, Meyer-Arnek J, Hildenbrand $\mathrm{B}$, et al. Influence of air pressure, humidity, solar radiation, temperature, and wind speed on ambulatory visits due to chronic obstructive pulmonary disease in Bavaria, Germany. Int J Biometeorol. 2012;56:137-43. https://doi.org/10. 1007/s00484-011-0405-x

18. Arbex MA, Santos Ude P, Martins LC, Saldiva PH, Pereira LA, Braga AL. Air pollution and the respiratory system. J Bras Pneumol. 2012;38:643-55.

19. Anderson JO, Thundiyil JG, Stolbach A. Clearing the air: a review of the effects of particulate matter air pollution on human health.J Med Toxicol.2012;8:166-75. https://doi.org/10.1007/ s13181-011-0203-1

20. Atkinson RW, Anderson HR, Strachan DP, Bland JM, Bremner SA, Ponce de Leon A. Short-term associations between outdoor air pollution and visits to accident and emergency departments in London for respiratory complaints. Eur Respir J. 1999;13:257-65.

21. Galán I, Tobías A, Banegas JR, Aránguez E. Short-term effects of air pollution on daily asthma emergency room admissions. Eur Respir J. 2003;22:802-8.

22. Peel JL, Tolbert PE, Klein M, Metzger KB, Flanders WD, Todd K, et al. Ambient air pollution and respiratory emergency department visits. Epidemiology. 2005;16:164-74.

23. Villeneuve PJ, Chen L, Rowe BH, Coates F. Outdoor air pollution and emergency department visits for asthma among children and adults: a case-crossover study in northern Alberta, Canada. Environ Health. 2007;6:40. https://doi.org/10.1186/ 1476-069X-6-40

24. Wang KY, Chau TT. An association between air pollution and daily outpatient visits for respiratory disease in a heavy industry area. PLoS One. 2013;8:e75220. https://doi.org/10.1371/journal.pone. 0075220

25. Zheng XY, Ding H, Jiang LN, Chen SW, Zheng JP, Qiu M, et al. Association between air pollutants and asthma emergency room visits and hospital admissions in time series studies: a systematic review and meta-analysis. PLoS One. 2015;10: e0138146. https://doi.org/10.1371/journal.pone.0138146

26. Arbex MA, de Souza Conceição GM, Cendon SP, Arbex FF, Lopes AC, Moysés EP, et al. Urban air pollution and chronic obstructive pulmonary disease-related emergency department visits. J Epidemiol Community Health. 2009;63:777-83. https: //doi.org/10.1136/jech.2008.078360

27. Stieb DM, Szyszkowicz M, Rowe BH, Leech JA. Air pollution and emergency department visits for cardiac and respiratory conditions: a multi-city time-series analysis. Environ Health. 2009;8:25. https://doi.org/ 10.1186/1476-069X-8-25

28. Tamayo-Uria I, Altzibar JM, Mughini-Gras L, Dorronsoro M. Exacerbations of chronic obstructive pulmonary disease
(COPD): an ecological study in the Basque County, Spain (2000-2011). COPD. 2016;13:726-33. https://doi.org/10.108 0/15412555.2016.1182145

29. Wong TW, Lau TS, Yu TS, Neller A, Wong SL, Tam W, et al. Air pollution and hospital admissions for respiratory and cardiovascular diseases in Hong Kong. Occup Environ Med. 1999;56:679-83.

30. Wong CM, Atkinson RW, Anderson HR, Hedley AJ, Ma S, Chau PY, et al. A tale of two cities: effects of air pollution on hospital admissions in Hong Kong and London compared. Environ Health Perspect. 2002;110:67-77.

31. Samoli E, Aga E, Touloumi G, Nisiotis K, Forsberg B, Lefranc $A$, et al. Short-term effects of nitrogen dioxide on mortality: an analysis within the APHEA project. Eur Respir J. 2006;27: 1129-38. https://doi.org/10.1183/09031936.06.00143905

32. Pintarić S, Bodrožić-Džakić T, Pintarić H, Rusan Z, Ljubičić S. Effects of nitrogen dioxide and meteorological conditions on the number of patients presenting to emergency department. Acta Clin Croatica.2012;51:9-14.

33. Cirera L, García-Marcos L, Giménez J, Moreno-Grau S, Tobías A, Pérez-Fernández V, et al. Daily effects of air pollutants and pollen types on asthma and COPD hospital emergency visits in the industrial and Mediterranean Spanish city of Cartagena. Allergol Immunopathol (Madr).2012;40:231-7.https:// doi.org/10.1016/j.aller.2011.05.012

34. Santus P, Russo A, Madonini E, Allegra L, Blasi F, Centanni S, et al. How air pollution influences clinical management of respiratory diseases. A case-crossover study in Milan. Respir Res. 2012;13:95. https://doi.org/10.1186/1465-9921-13-95

35. Leitte AM, Schlink U, Herbarth O, Wiedensohler A, Pan XC, $\mathrm{Hu} \mathrm{M}$, et al. Size-segregated particle number concentrations and respiratory emergency room visits in Beijing, China. Environ Health Perspect. 2011;119:508-13.

36. Liu P, Wang X, Fan J, Xiao W, Wang Y. Effects of air pollution on hospital emergency room visits for respiratory diseases: urban-suburban differences in eastern China. Int J Environ Res Public Health. 2016;13.pii:E341. https://doi.org/10.3390/ ijerph13030341

37. Shahi AM, Omraninava A, Goli M, Soheilarezoomand HR, Mirzaei N. The effects of air pollution on cardiovascular and respiratory causes of emergency admission. Emerg (Tehran). 2014;2:107-14.

38. Wilson AM, Wake CP, Kelly T, Salloway JC. Air pollution, weather, and respiratory emergency room visits in two northern New England cities: an ecological time-series study. Environ Res. 2005;97:312-21. https://doi.org/10.1016/j.envres. 2004.07.010

39. Kousha T, Rowe BH. Ambient ozone and emergency department visits due to lower respiratory condition. Int J Occup Med Environ Health. 2014;27:50-9. https://doi.org/10.2478/ s13382-014-0229-0 
Sažetak

\title{
KORELACIJA IZMEĐU POJAVE I POGORŠANJA RESPIRACIJSKIH BOLESTI I ONEČIŠĆENJA ZRAKA UNUTAR DOZVOLJENIH GRANICA
}

\author{
K. Trnjar, S. Pintarić, M. Mornar Jelavić, V. Nesek, J. Ostojić, S. Pleština, A. Šikić i H. Pintarić
}

\begin{abstract}
Željeli smo istražiti nepoznati utjecaj onečišćivača zraka na pojavnost ili pogoršanje bolesti dišnoga sustava u području s vlažnom kontinentalnom klimom. Ova retrospektivna studija je obuhvatila 5868 bolesnika s respiracijskom simptomatologijom (infekcija gornjih dišnih putova (IGDP), upala pluća, akutni bronhitis, kronična opstruktivna plućna bolest (KOPB) i astma) primljenih u hitnu službu. Podaci o broju bolesnika, vrijednostima meteoroloških parametara (srednje dnevne vrijednosti tlaka, temperature zraka i relativne vlage) i koncentracijama čestica onečišćenja zraka $\left(\leq 10 \mu \mathrm{m}_{(}\left(\mathrm{PM}_{10}\right)\right.$, ozona $\left(\mathrm{O}_{3}\right)$ i dušičnog dioksida $\left(\mathrm{NO}_{2}\right)$ ) prikupljeni su tijekom dvije godine (srpanj 2008. - lipanj 2010. godine). Bilo je 1839 (31,3\%), 1712 (29,2\%), 1313 (22,4\%), 614 (10,5\%) i 390 (6,6\%) bolesnika s upalom pluća, KOPB-om, IGDP-om, akutnim bronhitisom i astmom. Srednje dnevne koncentracije $\mathrm{NO}_{2}\left(25,9(1,7-89,7) \mu \mathrm{g} / \mathrm{m}^{3}\right), \mathrm{O}_{3}\left(47,1(4,7-135,4) \mu \mathrm{g} / \mathrm{m}^{3}\right)$ i čestica $\mathrm{PM}_{10}(25,7$ $\left.(4,6-146,6) \mu \mathrm{g} / \mathrm{m}^{3}\right)$ bile su ispod zakonski definirane granične vrijednosti. Među ostalim rezultatima, ukupna pojavnost bolesti dišnoga sustava bila je u pozitivnoj Spearmanovoj korelaciji s vlažnosti zraka (dani 0-3, $r=0,15-0,19)$ i koncentracijom čestica $\mathrm{PM}_{10}$ (dani 0-3, $r=0,10-0,13$ ) i $\mathrm{NO}_{2}$ (dan $0, r=0,11$ ), a u negativnoj korelaciji s temperaturom (dani 0-3, $r=-0,36$ do $-0,34)$ i tlakom zraka (dan $0, r=-0,10)$ te koncentracijom čestica $\mathrm{O}_{3}($ dani $0-3, r=-0,21$ do $-0,22)($ za sve p $<0,05)$. U zaključku, pojavnost bolesti dišnoga sustava pokazala je korelaciju s vremenskim uvjetima i onečišćivačima zraka unatoč zakonski dopuštenim vrijednostima u području s vlažnom kontinentalnom klimom.
\end{abstract}

Ključne riječi: Onečišćenost zraka - štetno djelovanje; Respiracijski poremećaji; Ozon; Dušikov dioksid; Hrvatska 